\title{
Implementasi Nilai-Nilai Keberagaman Dan Sikap Toleransi Antara Mayoritas Muslim Dengan Etnis China Di Desa Penagan
}

\author{
Achmad Ade Saputra $^{1}$, Hasnul hotimah ${ }^{2}$, Joko Supriyanto ${ }^{3}$, Piria Alfitri ${ }^{4}$, Sibawaihi ${ }^{5}$ \\ ${ }^{1}$ IAIN Syaikh Abdurrahman Siddik Bangka Belitung \\ ${ }^{2}$ IAIN Syaikh Abdurrahman Siddik Bangka Belitung \\ ${ }^{3}$ IAIN Syaikh Abdurrahman Siddik Bangka Belitung \\ ${ }^{4}$ IAIN Syaikh Abdurrahman Siddik Bangka Belitung \\ ${ }^{5}$ IAIN Syaikh Abdurrahman Siddik Bangka Belitung
}

Info Artikel :

Diterima : 31 desember 2020

Direvisi: 28 februari 2021

Dipublikasikan : 30 april 2021

\section{Kata Kunci:}

Nilai-nilai keberagman

Sikap toleransi

Mayoritas muslim dan etnis

China

\begin{abstract}
ABSTRAK
Penelitian ini mengkaji nilai-nilai toleransi antara mayoritas muslim dengan etnis china di desa Penagan. Penelitian menggunakan pendekatan kualitatitif dengan metode etnografi. Teknk pengumpulan data dalam menghimpun data dan informasi yaitu observasi, wawancara, dan dokumentasi. Yang menjadi subjek penelitian ini adalah pemerintah desa Penagan, Tokoh Muslim, dan Tokoh etnis China. dalam peneltian mengkaji bagaimana bentuk intraksi sosial dan toleransi dalam beragaman suku budaya dan Agama. dalam hal ini masyarakat ethnis china yang telah menetap lama di desa penagan bahwasanya mereka sudah menjadi penduduk asli di desa penagan besar dan hidup disanalah, sehingga tidak ada perbedaan ataupun sikap diskriminasi dari beberapa pihak. Bahwasanya meskipun dalam segala perbedaan mereka bisa hidup bergandengan tangan saling membantu antara masyarakat melayu dan masyarakat ethnis china dengan prinsipfan ngin, to ngin jit jong, yang berarti "pribumi melayu, dan etnis China semuanya sama dan setara", rekomendasi penelitian kepada pemerintah desa Penagan utnuk tetap menjaga kerukunan dan keamanan antar umat beragama.
\end{abstract}

Kata kunci: Nilai-nilai Keberagaman, Sikap Toleransi, Mayoritas Muslim, dan Etnis China

\begin{abstract}
This study examines the values of tolerance between the majority of Muslims and ethnic Chinese in Penagan village. This research uses a qualitative approach with ethnographic methods. Data collection techniques in collecting data and information are observation, interviews, and documentation. The subjects of this research are the Penagan village government, Muslim leaders and ethnic Chinese leaders. In this research, it examines how the forms of social interaction and tolerance in various ethnic cultures and religions. In this case, the Chinese ethnic community who have lived for a long time in the Penagan Village are aware that they have become indigenous people in the Penagan Besar village and live there, so there is no difference or discriminatory attitude from some parties. it means that even though in all their differences they can live helping each other between the Malay community and the Chinese ethnic community with the principle of fan ngin, to ngin jit jong which means "native Malay, and ethnic Chinese are
\end{abstract}


same and equal", the research recommendation is the Penagan village government to maintain harmony and security between religious communities.

Keywords: Diversity values, attitude of tolerance, Muslim majority, and Chinese ethnicity

\section{Koresponden:}

This is an open access article distributed under the Creative Commons Attribution License, which permits unrestricted use, distribution, and reproduction in any medium, provided the original work is properly cited. $(2019$ by author.

Achmad Ade Saputra, Hasnul Hotimah, Joko Supriyanto, Piria Alfitri, Sibawaihi

Gmail: Ahmadadeputra56@gmail.com, atnawatiw@gmail.com,jokosupriyanto09798@gmail.com, piriaalfitri747@gmail.com, Sibawaihiassaimi01012000@gmail.com

\section{Pendahuluan}

Desa Penagan adalah salah satu dari 13 desa di Kecamatan Mendo barat, Kabupaten Bangka, Provinsi Bangka Belitung, Indonesia. Desa ini terletak di sisi Selat Bangka yang mengahadap ke Sumatra. Bagian utara berbatasan dengan desa Kota Kapur. Desa yang memiliki kode pos 33173 ini dibentuk pada tahun 1999. Pada tahun 2018, jumlah penduduknya sebanyak 4.704 jiwa, Desa Penagan berjarak hampir $50 \mathrm{~km}$ dari Pangkalpinang dan dapat ditempuh dalam waktu sekitar 1 jam dengan mobil. Desa ini memiliki dua mayoritas agama yakni Islam dan China. Kedua agama tersebut berinteraksi sosial dengan baik sehingga terciptanya kehidupan yang damai, aman, tentram, rukun, dan sejahtera. Toleransi beragama merupakan sikap saling menghormati dan menghargai antar penganut agama lainnya. (Kuntowijoyo, 2005). Dengan ini toleransi beragama mengajarkan kepada masyarakat Desa Penagan untuk saling menghargai, menghormati dan tidak membeda-bedakan setiap perbedaan agar terjalin interaksi yang baik di Desa Penagan tersebut.

Keberagaman yang melekat pada kedua agama tersebut membuat Desa Penagan memiliki jiwa toleransi yang sangat baik. Hal ini dilatarbelakangi oleh sikap ramah, tamah, sikap saling menghargai, dan menghormati antar sesama masyarakat di daerah tersebut yang tidak memandang perbedaan yang ada di dalam kemajemukan itu.

Dalam hal ini keberagamaan bisa saja menjadi tantangan karena setiap orang memiliki perbedaan. Perbedaan ini menyebabkan sebagian orang yang kehilangan kendali, diantara keberagamaan lainnya seperti keberagamaan agama dan keyakinan yang diterima oleh masyarakat Desa Penagan sebab sebelumnya masyarakat sudah mengenal suatu kepercayaan dinamisme dan animisme, (Arif, 2018). Meskipun adanya perbedaan yang menjadi batasan terkait akidah umat beragama, tetapi pada hakikatnya perbedaan itu merupakan suatu keniscayaan di dunia ini, dengan adanya perbedaan seharusnya menjadi sebuah warna yang menarik dalam kehidupan bermasyarakat.

Pada dasarnya nilai sosial yang dianut dalam masyarakat dipengaruhi oleh budaya dan keyakinan yang dianut dalam masyarakat, (Liliweri, 2005). Dengan demikian bidang keagamaanpun dalam implementasi pelaksanaan peribadatan dipengaruhi oleh perkembangan zaman dan kondisi sosial masyarakat. Salah satu hal yang dapat merubah perbedaan menjadi sebuah keragamaan yang menarik adalah dengan menanamkan sikap toleransi dalam menyikapi segala bentuk perbedaan. Toleransi dalam Islam telah menjadi ciri khas bagi umat Islam, karena Nabi Muhammad SAW dalam menyebarkan Agama Islam sangat terkenal degan sikap toleransinya.

Dengan latar belakang tersebut, maka peneliti tertarik untuk mengkaji tentang bagaimana seharusnya nilaai-nilai, bentuk, dan sikap toleransi serta hubungan sosial dalam masyarakat memiliki dua mayoritas agama yang berbeda tetapi tetap menjaga sikap tolernasi dan tidak bersifat radikalisme antara satu dengan lainnya, serta tidak mengedepankan kepentingan masing-masing dan tidak bersifat inklusif namun tetap bisa menjaga sikap yang baik dalam moderasi beragama. Dengan ini peneliti mengangkat tema moderasi beragama dengan judul Implementasi Nilai-nilai Keberagaman dan Sikap Toleransi Antara Mayoritas Muslim dan Etnhis China di Desa Penagan. 
Metode

Penelitian ini menggunakan pendekatan kualitatif dengan metode etnografi. Pendekatan etnografi dilakukan untuk mendeskripsikan fenomena interaksi antar etnis yang didapatkan dari partisipan penelitian secara alamiah. Fenomena yang berkenaan dengan pengetahuan, keyakinan-keyakinan, nilainilai, norma-norma, tradisi-tradisi, bahasa, dan praktek kehidupan sehari-hari. Teknik pengumpulan data melalui wawancara, observasi, dan dokumentasi. Yang menjadi objek penelitian atau sebagai partisipan pada penelitian ini terdiri dari pemerintah desa Penagan, tokoh Muslim desa Penagan dan Tokoh etnis China desa Penagan ( pemerintah desa Penagan: Ismail As'an dan Effendi. Tokoh Muslim: H. Hasyim Abdul Manaf dan bapak Abdul Kadir. Tokoh etnis China: Anen dan Aliong).

\section{Hasil dan Pembahasan}

Toleransi merupakan suatu upaya untuk mewujudkan suatu masyarakat harmonis yang dilakukan secara terus menerus dan bersama- sama oleh segenap lapisan masyarakat. Dalam kehidupan sehari-hari Sebagai makhluk sosial, manusia memerlukan interaksi dengan orang lain. Interaksi sosial yang dilakukan oleh mayoritas muslim dengan etnis china di desa Penagan terjadi dalam tiga aspek interaksi dan toleransi yaitu di aspek agama, budaya, dan sosial.

Berdasarkan hasil wawancara dan observasi yang dilakukan peneliti di desa Penagan tentang implementasi nilai-nilai toleransi antara mayoritas muslim dan etnis China di desa Penagan yang menjadi fokus penelitian ini pada aspek interaksi dan toleransi dalam kehidupan sehari-hari baik dari aspek agama, sosial, dan budaya. Hubungan interaksi masyarakat mayoritas muslim dengan etnis china dalam aspek agama adalah menghargai/menghormati keyakinan masing-masing, tidak memaksa seseorang untuk memeluk suatu agama tertentu, dan tidak mendiskriminasikan salah satu dari kedua agama tersebut.

Hubungan interaksi dan toleransi masyarakat muslim dengan etnis china dalam masalah keagamaan cukup menarik hal ini terlihat dari kuatnya kerukunan yang tercipta sejak dahulu zaman penjajahan sampai sekarang. Berdasarkan pengamatan dan wawancara peneliti, kerukunan antar umat beragama dengan sangat baik. Tidak hanya antar pemeluk agama Islam dengan etnis China saja, namun juga kerukunan umat ada dalam pemeluk agama Kristen. Pada hari besar keagamaan, sangat terlihat bagaimana masyarakat sangat toleransi kepada pemeluk agama lain. Perayaan hari besar keagamaan tidak hanya disambut dan dirayakan secara antusias oleh penganutnya saja, namun juga dirayakan dan disambut oleh penganut agama lain. Kerukunan antar umat beragama pada masyarakat desa penagan terlihat dari kebebasan umat untuk beribadah, saling memberikan selamat dan bersilaturahmi saat hari besar keagamaan.

Bagi umat Islam, hari besar keagamaan dirayakan di hari raya idul fitri, idul adha, dan tahun baru Islam. Adapun perayaan hari besar keagamaan etnis China yakni pada perayaan Imlek. Pada hari-hari tersebut, umat yang merayakan akan mengadakan open house, menyediakan berbagai macam makanan dan minuman yang biasa disajikan di hari raya. Terkhusus di daerah yang didiami oleh etnis China di desa Penagan yakni kampung paret dan batu ampar, siswa-siswa diberikan Izin khusus untuk tidak hadir mengikuti pelajaran saat melaksanakan sembahyang rebut, merayakan ceng beng dan Imlek. Bahkan tak jarang guru-guru, umat muslim diundang oleh wali murid pada saat perayaan Imlek.

Toleransi dan interaksi sosial antar etnis China dan melayu dalam aspek sosial kemasyarakatan. Kegiatan amal yang dilakukan oleh etnis China setiap tahun di desa Penagan adalah saat menyelenggarakan kegiatan sembahyang rebut. Sembahyang rebut merupakan ritual keagamaan etnis China yang acaranya berupa pembagian makanan, bahan sembako, dan uang yang akan diperebutkan setelah sembahyang selesai. Sugiri dan Jauhari menyatakan bahwa masyarakat etnis China yang merupakan etnis minoritas tidak menghalangi mereka untuk berpartisipasi dalam kegiatan sosial kemasyarakatan. Etnis China menggunakan istilah-istilah kekerabatan, penyebutan nama saja (tanpa menyertakan istilah-istilah kekerabatan) untuk mengekspresikan kesantunan positif, (Jauhari, 2013). Selain memberikan amal kepada etnis China, mereka juga membagikan kepada masyarakat sekitar yang kurang mampu.

Pemerintah desa Penagan memberikan ruang kepada etnis China untuk terlibat dalam kegiatan kemasyarakatan, pemerintah juga melibatkan etnis China dalam acara-acara bakti sosial, gotong royong, 
dan lain sebagainya. Selain itu setiap masyarakat melaksanakan resepsi pernikahan, baik etnis China maupun muslim akan diundang diacara tersebut. Dilain kesempatan pada perayaan hari besar keagamaan seluruh masyarakat desa Penagan ikut melaksanakan dengan suka cita seperti pada perayaan Nisfu Sya'ban atau sering dikenal oleh masyarakat sekitar dengan sebutan ruwahan yang menjadi acara keagamaan terbesar dan ramai di desa Penagan dibandingkan dengan perayaan idul fitri dan idul adha yang menjadi ciri khas Desa Penagan.

Kehidupan masyarakat muslim dan etnis China di desa Penagan sering melibatkan diri dalam kegiatan gotong royong membersihkan lingkungan bakti sosial, undangan resepsi pernikahan, dan acara kematian. Pertemanan atau ikatan persaudaraan antara etnis China dan muslim tercipta dikarenakan tempat tinggal mereka yang berdekatan dan tingkat ekonomi mereka yang setara dan dalam satu rumpun melayu karena sering bertemu dikarnakan jarak rumah yang berdekatan, tentu akan saling mengenal satu sama lain dan sering menjalin komunikasi antar keduanya. Etnis China dan muslim akrab sama seperti orang sesama etnis yang mencari sahabat karena tidak pernah memandang dari mana mereka berasal, dikarenakan persamaan hobi atau lingkungan tempat tinggal yang satu, (Ihsan, 2009).

Berdasarkan hasil wawancara oleh tim KKN DR Kecamatan Mendo Barat 4 di desa Penagan strategi interaksi sosial antara etnis China dan muslim tidak pernah menganggap salah satunya yang paling baik, tidak adanya diskriminasi dalam pergaulan sehari-hari hal ini dibuktikan dengan data yang peniliti dapatkan di lapangan sejak datangnya etnis China dan bergabung dengan muslim di desa Penagan. Beberapa bentuk kegiatan interaksi yang terjadi anatara etnis China dan muslim adalah pada perayaan ruwahan atau malam Nisfu Sya'ban yang dilaksanakan oleh masyarakat desa Penagan sebagai salah satu upaya menjaga solidaritas dan kerukunan anatara etnis China dan muslim. Adapun perayaan ruwahan pada tahun 2019 bertepatan dengan tanggal 21 April yang diselenggarakan oleh pemerintah desa Penagan dan dibantu oleh karang taruna diisi dengan kegiatan perlombaan mulai dari seni dan olahraga. Seni yang ditampilkan pada perayaan ruwahan tersebut meliputi gambus, rudat dan bedincak. Adapun perlombaan dalam bidang oleharaga untuk memeriahkan acara ruwahan ini biasanya dibuka open turnamen Ruwah CUP Cabor sepak bola, bola voly, badminthon dan sepak takraw.

Strategi yang dilakukan oleh etnis China dan muslim dalam melakukan interaksi sosial terjadi di dalam berbagai bidang. Suekanto menyatakan: "sistem kemasyarakatan mencakup berbagai bidang kehidupan yang merupakan subsistem, oleh karena menjadi bagian satu kesatuan yang menyeluruh. Biasanya subsistem tersebut terdiri dari subsistem agama, subsistem sosial, subsistem budaya". Berikut penjelasan etnis China dan melayu di desa Penagan dalam berbagai aspek, (Hamali, 2017)

\section{Nilai-nilai Keberagaman dan Sikap Toleransi Etnis China dan Muslim Desa Penagan Di Bidang Agama}

Di desa Penagan, ada beberapa agama yang diakui yaitu Islam, Konghucu dan Kristen. Masyarakat desa Penagan mayoritasnya beragama muslim. Hal ini dapat dilihat dari bangunan rumah ibadah yang bisa dijumpai di berbagai dusun di desa Penagan. Agama mayoritas kedua yang dianut oleh masyarakat desa Penagan adalah Konghucu dan Kristen.

Islam sebagai agama mayoritas memiliki peran penting dalam interaksi sosial antar etnis. Islam menganggap perbedaan sebagai sunnatullah, sehingga umat Islam dapat lebih menerima dengan baik perbedaan dibandingkan dengan agama yang lain. Hal ini didukung dengan teori yang dikemukakan oleh Idi bahwa Islam salah satu elemen penting dari penganut agama mayoritas dalam bangsa pluralitas ini, memiliki peran, fungsi signifikan, dan strategis sebagai "perekat" integrasi sosial dan integrasi bangsa.

Masyarakat muslim memberikan toleransi yang tinggi kepada pemeluk agama lain, sehingga kedamaian yang diciptakan oleh orang muslim mempengaruhi pola fikir non muslim untuk menghargai atau toleransi dengan orang yang berbeda agama. Orang melayu yang mayoritas muslim memang mengikuti ajaran Islam yang universal dan cinta damai sehingga mereka cendrung menerima pendatang dengan prasangka baik (husnudzhan) kepada siapapun atau apapun, sehingga orang muslim memiliki sifat tulus dalam bergaul. Etnis China menganggap agama Islam sebagai agama alternatif yang baik, jadi tidak heran apabila etnis China ada yang menjadi muallaf, baik karena keinginan diri sendiri maupun karena 
pernikahan. Contohnya yaitu anak salah satu warga etnis China yang masuk Islam atau menjadi muallaf karena pernikahan, (Koentjaraningrat, 2010).

Etnis China tidak menganggap pernikahan antar etnis dan menjadi muallaf sebagai hal yang tidak pantas karena menjadi muallaf dan menikah antar etnis sebagai hal yang tidak pantas, karena pernikahan antar etnis dan menjadi muallaf telah terjadi sejak dahulu yakni pada saat penjajahan datang ke Bangka."Pada abad 18 Masehi saat kedatangan etnis China datang ke Bangka untuk menjadi buruh tambang. Berdasarkan data dari beberapa informan, kerukunan umat beragama di desa Penagan ini dikarenakan sikap saling menghormati, toleransi, dan kerja sama sesuai dengan pedoman masyarakat Bangka "sepintu sedulang" sikap saling menghormati, toleransi dan bekerja sama merupakan warisan leluhur yang tetap terjaga hingga saat ini "ungkap bapak Effendi selaku aparat desa Penagan.

Kerukunan umat beragama di Bangka dapat terjaga karena masing-masing umat beragama diberikan kebebasan untuk memeluk suatu agama tanpa paksaan, dan dukungan dari pemeluk agama lain saat merayakan hari besar keagamaan.

\section{Nilai-nilai Keberagaman dan Sikap ToleransiEtnis China Dan Muslim Penagan Di Bidang Sosial Kemasyarakatan}

Tidak mengherankan dalam sebuah kehidupan masyarakat adanya hubungan antara manusia satu dengan lainnya. Salah satunya adalah interaksi dalam sosial kemasyarakatan, jadi sewajarnya dalam kehidupan sehari-hari adanya hubungan tersebut. Etnis china dan muslim banyak terlibat interaksi dalam berbagai bidang dimasyarakat, penyesuaian diri etnis China kepada muslim desa Penagan telah berlangsung sejak lama semenjak kedatangan mereka kepulau Bangka terkhusus di desa Penagan sendiri. Setelah etnis China menjadi penduduk Indonesia, mereka juga terlibat dalam kegiatan sosial kemasyarakatan, pergaulan dimasyarakat, berteman dekat dengan etnis lain, terlibat dalam kegiatan bakti sosial, perayaan hari besar keagamaan, undangan pernikahan, dan acara kematian. Hal ini mendukug teori Gillin yang menyatakan bahwa akomodasi membuka jalan ke arah asimilasi, para pihak lebih saling mengenal dan dengan timbulnya benih-benih toleransi mereka lebih mudah untuk mendekati, (Soekanto, 2009).

Ada beberapa faktor yang mempengaruhi kuatnya toleransi didesa penagan antara etnis china dan mayoritas muslim dapat beteman dan bergaul dengan baikantara lain karena pemukiman, persamaan tempat kerja atau sekolah. Kesetaraan ekonomi juga membuat tidak adanya kesenjangan sosial yang menjadikan kehidupan bertetangga akur dan tentram. Selain itu bagi etnis China dan muslim yang sudah menjadi muallaf, beragama Islam lebih mudah untuk diterima di masyarakat.

Teori-teori yang menunjang dan hasil observasi dan wawancara bahwa interaksi sosial yang terjadi pada etnis china dan muslim di desa penagan keragaman mereka disatukan dengan semboyan fan ngin, to ngin jit jong, yang berarti "Pribumi melayu, dan etnis China semuanya sama dan setara" sehingga hubungan dari keberagaman tersebut berjalan dengan baik diberbagai aspek. Tidak terdapat diskriminasi terhadap etnis china yang menjadi etnis minoritas. Interaksi sosial yang asimilatif itu terjadi secara relatif dan natural sempurna dipengaruhi oleh keadaan sosial dan ekonomi masyarakat desa penagan, (Idi, 2012). Orang yang merupakan etnis mayoritas bersikap terbuka, memiliki prasangka yang rendah dan mau merangkul etnis-etnis lain dalam pergaulan sehari-hari membuat interaksi antara etnis china dan muslim desa penagan semakin erat.

\section{Nilai-nilai Keberagaman dan Sikap Toleransi Etnis China dan Muslim desa Penagan dalam bidang Adat dan Budaya}

Berdasarkan hasil wawancara dengan bapak Effendi selaku pemerintah desa Penagan ia mengatakan " bahwa toleransi didesa Penagan sangat baik dikarenakan belum pernah terjadi konflik agama yakni diberi kebebasan kepada setiap orang memilih kepercayaan dan keyakinan masing-masing. Ketika kedua agama merayakan hari besar keagamaan masing-masing mereka saling bersilahturahmi/bertamu kerumah salah satu dari perayaan tersebut. Faktor yang mempengaruhi kuatnya 
toleransi kedua agama tersebut didesa penagan adalah pertama, faktor adat yang mana menjunjung tinggi nilai-nilai adat yang ada di desaPenagan, tidak ada saling mendiskriminasi serta memprovokasi satu dengan yang lainnya. Kedua, faktor agama yang mana mengajarkan untuk saling menghargai, menghormati keyakinan masing-masing serta mempertahankan selagi tidak melanggar aturan. Ketiga, faktor sosial yang mana interaksi sosial kedua agama tersebut tidak pernah saling membedakan satu sama yang lainnya.

Berdasarkan hasil wawancara dengan bapak H. Hasyim Abdul Manap selaku pemuka agama Islam ia mengatakan " bahwa toleransi kedua agama saling menghargai serta memghormati keyakinan masing-masing. Interaksi sosial kedua agama tersebut terjalin dengan baik, sebagai pemuka agama saya sangat menjunjung tinggi toleransi antar umat beragama tapi dilain hal kita punya batasan masing-masing perihal akidah, Karena tidak ada toleransi dalam hal akidah selain itu boleh bertoleransi dalam kehidupan sehari-hari.

Berdasarkan hasil wawancara dengan bapak Anen selaku salah satu warga etnis China ia mengatakan "di desa Penagan belum ada perselisihan atau pertikaian dari kedua agama tersebut walaupun dalam satu desa terdapat perbedaan keyakinan dan lainnya. Adapun sikap toleransi yang ditunjukkan ialah tidak ada saling benci membenci dari kedua agama tersebut bahkan sudah menganggap seperti keluarga sendiri. Interaksi sosial dengan agama Islam seperti biasanya terjalin dengan baik layaknya saudara sendiri.

\section{Kesimpulan}

Masyarakat etnis China dan Melayu memiliki semboyan yaitu fan ngin, to ngin jit jong, yang berarti 'pribumi Melayu, dan China turunan semuanya sama dan setara'. Oleh karena itu, hubungan kekeluargaan antar warga melayu dan China di Bangka tidak secara kebetulan, tetapi karena merasa sebagai satu keluarga besar yang diawali hubungan para leluhur hingga saat ini. Sikap menerima status etnis China dan melayu sederajat menciptakan harmonisasi dalam kehidupan bermasyarakat sehingga diskriminasi bahkan konflik yang melibatkan SARA, tidak pernah terjadi di Kabupaten Bangka.

Faktor yang mempengaruhi kuatnya toleransi kedua agama tersebut didesa penagan adalah pertama, faktor adat yang mana menjunjung tinggi nilai-nilai adat yang ada di desa Penagan, tidak ada saling mendiskriminasi serta memprovokasi satu dengan yang lainnya. Kedua, faktor agama yang mana mengajarkan untuk saling menghargai, menghormati keyakinan masing-masing serta mempertahankan selagi tidak melanggar aturan. Ketiga, faktor sosial yang mana interaksi sosial kedua agama tersebut tidak pernah saling membedakan satu sama yang lainnya.Adanya kesetaraan status antara etnis China dan melayu menyebabkan interaksi sosial diberbagai bidang berjalan dengan baik dan sebagaimana mestinya. Kesatuan yang selama telah terjalin dapat terus dipertahankan hingga saat ini.

\section{Referensi}

Arif, F. M. (2018). Maqashid as Living Law dalam Dinamika Kerukunan Umat Beragama di Tana Luwu. Deepublish.

Hamali, S. (2017). Agama dalam Perspektif Sosiologis. Al-Adyan: Jurnal Studi Lintas Agama, 12(2), 223244.

Idi, A. (2012). Interaksi Sosial "Natural-Asimilatif" antara Etnis Muslim Cina dan Melayu-Bangka. Thaqafiyyat.

Ihsan, A. B. (2009). Menebar toleransi, menyemai harmoni: SBY dalam wacana perdamaian, moderatisme, dan keadilan. Remaja Rosdakarya.

Jauhari, E. (2013). Kesantunan positif dalam masyarakat etnik Tionghoa di surakarta.

Koentjaraningrat, K. (2010). Manusia dan kebudayaan di Indonesia.[Humans and culture in Indonesia]. Jakarta: Djambatan.

Kuntowijoyo, D. R. (2005). Pengantar ilmu sejarah. Bentang Pustaka. 
Liliweri, A. (2005). Prasangka dan Konflik; Komunikasi Lintas Budaya Masyarakat Multikultur. LKiS Pelangi Aksara.

Soekanto, S. (2009). Sosiologi suatu pengantar, edisi baru. Jakarta: Rajawali Pers. 